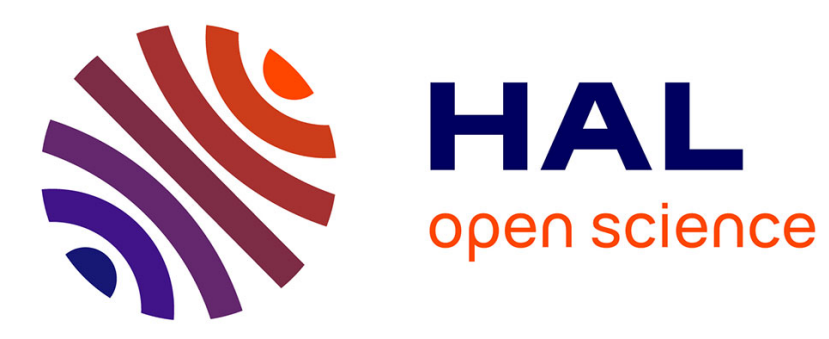

\title{
Buddhism, Daoism, and Chinese Religion
}

Stephen Teiser, Franciscus Verellen

\section{To cite this version:}

Stephen Teiser, Franciscus Verellen. Buddhism, Daoism, and Chinese Religion. Cahiers d'ExtrêmeAsie, 2011, 20 (1), pp.1-12. 10.3406/asie.2011.1365 . halshs-02427046

\section{HAL Id: halshs-02427046 https://shs.hal.science/halshs-02427046}

Submitted on 3 Jan 2020

HAL is a multi-disciplinary open access archive for the deposit and dissemination of scientific research documents, whether they are published or not. The documents may come from teaching and research institutions in France or abroad, or from public or private research centers.
L'archive ouverte pluridisciplinaire HAL, est destinée au dépôt et à la diffusion de documents scientifiques de niveau recherche, publiés ou non, émanant des établissements d'enseignement et de recherche français ou étrangers, des laboratoires publics ou privés. 


\section{Buddhism, Daoism, and Chinese Religion}

Stephen F. Teiser, Franciscus Verellen

\section{Citer ce document / Cite this document :}

Teiser Stephen F., Verellen Franciscus. Buddhism, Daoism, and Chinese Religion. In: Cahiers d'Extrême-Asie, vol. $20,2011$. Buddhism, Daoism, and Chinese Religion. pp. 1-12;

doi : https://doi.org/10.3406/asie.2011.1365

https://www.persee.fr/doc/asie_0766-1177_2011_num_20_1_1365

Fichier pdf généré le 06/02/2019 


\title{
Buddhism, Daoism, and Chinese Religion
}

\author{
Stephen F. TeIser \& Franciscus Verellen
}

The articles published in this volume represent some of the best recent work on a vast subject: the interaction between Buddhism and Daoism and the consequences of those connections for understanding Chinese religion. Early versions of these essays were presented at a conference held at Princeton University in October, 2010, through the sponsorship of the David A. Gardner'69 Magic Project (Council on the Humanities of Princeton University) and the École française d'ExtrêmeOrient. As organizers of the conference, we were conscious of the antiquity of the conceptual challenges raised by the confrontation of Buddhism and Daoism, and our assessment of the state of research influenced our design of the conference. Now, as guest editors of Cabiers d'Extrême-Asie, we think it fitting to provide here a brief orientation to the articles that follow, outlining our understanding of the field. Our discussion focuses on the relationship between Buddhism and Daoism, the question of sources, and recent areas of research.

\section{The Larger Context}

The emergence of "Chinese religion" in the post-classical age occurred in the context of China's encountcr with Indian civilization. Viewed from China, the indigenous religion proved remarkably receptive to the imprint of Buddhism, introduced via the commercial routes linking China with Central Asia and India, notwithstanding the deep roots of Daoism in the thought system and practices of Chinese antiquity and the fact that the Buddhist ideal of a celibate samgha was fundamentally at odds with the Confucian kinship system and ancestor cult. Indeed, the foreign religion met with near universal success in China-especially in regard to its vision of life after death, its teaching on morality, its practice of iconic representation, mortuary ritual, even monastic life and institutions. That attraction has lasted-or been reborn-despite periodic polemics and incidents of persecution, throughout the formative period of Chinese religion and into the present.

It is probably no coincidence that two of the most formative periods in the history of Daoism were also periods of strong interaction with Buddhism: the constitution in the fifth century of the Lingbao scriptural corpus, marking the massive entry of Buddhist doctrines and rituals into the Daoist canon, and the arrival of Tantric forms of Buddhism especially during the Tang dynasty (618-907) that transformed Daoist liturgy, art, and practices under the Song (960-1279).

Stepping back from the Chinese perspective, the same Sino-Indian interaction can be viewed from the vantage point of the spread of Buddhism across Asia. Wherever Buddhism entered into contact with different civilizations, societies, thought 
systems, or ritual practices, it adapted, acculturated, reformed. The inculturation of Buddhism in the Chinese environment profoundly marked both sides. From the point of view of Buddhism's progress through Asia, the hybridization resulting from interactions with Daoism is but one product of the cross-cultural encounters along the many routes of the journey of Buddhism from India and Sri Lanka through Central Asia, the Himalayas, the steppes, Southeast Asia, and Korea and Japan.

The complex of "Buddhism, Daoism, and Chinese Religion" deserves the attention of scholars of Asian religions, firstly, as the nexus of religious practice in China, and secondly as a stage in the evolution of Buddhism, a teaching that, through its historical interaction with extremely diverse local religious traditions, has been continuously enriched and modified. The precise nature of this interaction, meanwhile, is correspondingly complex and resistant to generalization. Central to the debate surrounding the papers at the 2010 conference was the attempt to bring into sharper focus such terms as "influence," "blending," and "borrowing," concepts with which art historians have also grappled for some time.

\section{Conceptualizing the Relationship between Buddhism and Daoism}

Some of the earliest surviving written evidence concerning Buddhism in China suggests that devotees conducted sacrifices jointly to Laozi t $^{\prime}$ and the Buddha. One example was Liu Ying 劉英 (d.u.), a younger brother of Emperor Ming 明帝 (r. 57-75), who followed the teachings of the Yellow Emperor 黃帝 and Laozi, sponsored Buddhist feasts for monks and laypeople, and observed the Buddhist fast days. The other was the Emperor Huan 桓帝 (r. 146-168), who arranged images of Laozi and Buddha under ostentatious canopies and, to the accompaniment of court music, had animals sacrificed to them.' While the veracity and dating of these Han dynasty sources are not beyond doubt, the general situation of Chinese religious practice is clear: Buddhism and Daoism were often conflated.

Early Chinese thinkers were well aware of the issue and tried to make sense of the relationship between the two traditions. Like the theology of other religions, this internal reflection required a model of religion that would position the different religions, as well as non-religions, in relation to one another. In the Chinese vocabulary, notions of legitimacy, superiority or secularity were expressed in the juxtaposition of pairs like inner and outer, Chinese and foreign, white and black,

I. For analysis of the primary sources, see Paul Demiéville, "Philosophy and Religion from Han to Sui," in The Cambridge History of China, vol. I: The Ch'in and Han Empires, $22 I$ B.C. - A.D.220, edited by Denis C. Twitchett and Michael Loewe (Cambridge: Cambridge University Press, 1987), 821-26; Henri Maspero, "An Essay on Taoism in the First Centuries A.D.," in Taoism and Chinese Religion, translated by Frank A. Kierman, Jr. (originally published in French in 1950; Amherst: The University of Massachusetts Press, 1981), 400-12; Tang Yongtong 湯用肜, Han Wei Liangjin Nanbeichao fojiao shi 漢魏兩百南北朝佛教史 (1938; reprint ed. in one vol., Taipei: Dingwen shuju 鼎文書局, 1976 ), 53-57; and Erik Zürcher, The Buddhist Conquest of China: The Spread and Adaptation of Buddhism in Early Medieval Cbina, third ed. (first ed. 1959; Leiden: E.J. Brill, 2007), 26-27, 36-38. 
or right and left. ${ }^{2}$ One of the most influential notions was a story, susceptible to a variety of interpretations, based on an early legend about Laozi. The simplest version of the narrative of the "conversion of the barbarians" (buabu 化胡) says that after putting his wisdom into words in the Daode jing 道德經 and journeying westward, Laozi continued into India, where he preached Buddhism as a form of his original Chinese teaching. ${ }^{3}$ In the second and third centuries CE the basic myth does not appear to have been interpreted agonistically. Rather, "conversion" or "transformation" simply implied alteration or change, suggesting that neither the original nor the transformed doctrine is superior.

By the beginning of the fourth century, however, Daoist writers interpreted the process of change as dilution or decay. In this reading, the teaching of Säkyamuni was at best a second-order reflection of Daoism, at worst a crude Indian medication that would prove toxic to civilized Chinese. Buddhist apologists were quick to respond, claiming that Laozi was in fact a lesser incarnation or disciple of the Buddha. The debate continued for centuries, including the production and banning of numerous versions of The Scripture on Converting the Barbarians by both sides. The metaphor of conversion was put to rest-or perhaps transformed again - only during the Yuan dynasty, when Buddhist advisors convinced Khubilai Khan that, in a multi-ethnic empire, it was wiser to follow Buddhist models for state religion and to quash propaganda hinting at the inferiority of non-Han groups. After ritualized debates and contests in 1258 , all intact versions of The Scripture on Converting the Barbarians were supposed to be confiscated, a presage of the government's alleged burning of all texts in the Daoist canon of $128 \mathrm{I}$ except for the Daode jing.

As modern scholars of religion, the contributors to this issue of Cabiers bring critical acumen to the question of similarities and differences between Buddhism and Daoism. As we have seen, "converting the barbarians" as a figurc of speech has a long and complicated history. At first invoked to explain the identity or similarity between religious practices, the idea was later used by Buddhist and Daoist elites jockeying for state support to assert difference and superiority. Modern historians are sensitive to the problem of whether this (and other terms) are being used to claim similarity or difference. Scholars not only attend to who is making the argument and for what purposes, but are also conscious of the long arm of the state, even in the early centuries of the Chinese imperium, and the efforts by church leaders to negotiate favorable terms for the licensing of their religious programs.

2. Cf. T.H. Barrett, "The Advent of the Buddhist Conception of Religion in China and Its Consequences for the Analysis of Daoism," Sungkyun Journal of East Asian Studies 9, no. 2 (2009): 149-65.

3. On the conversion of the barbarians, see Charles D. Benn, "Huabu jing," in The Routledge Encyclopedia of Taoism, edited by Fabrizio Pregadio (London and New York: Routledge, 2008), 492-94; Fukui Kōjun 福井康順, Dōkyō no kisoteki kenkyū 道教の基礎的研究 (Tokyo: Shoseki bunbutsu ryūtsūkai 籍文物流通會, 1958), 156-324; Anna Seidel, "Le sūtra merveilleux du Ling-pao Suprême, traitant de Laotseu qui convertit les barbares (manuscrit S. 208I) - contribution à l'étude du Bouddho-taoïsme des Six Dynasties," in Contributions aux études de Touen-bouang, vol. 3. Publications de l'École française d'Extrême-Orient, 135, edited by Michel Soymié (Paris: École française d'Extrême-Orient, 1984), 305-52 ; Zürcher, The Buddhist Conquest of China, 288-302. 
Moreover, the articles here are based on recent insights into the nature of religious identity in China. Rather than assuming the more exclusive worldview of their Buddhist or Daoist informants, modern scholars are increasingly cognizant of the different forms that religious identity takes in the Chinese setting. The very question of religious belonging - and hence of similarity to or difference from another religious tradition-has traditionally been asked by only a small number of people in Chinese history, either members of the Buddhist and Daoist elite or the broader educated elite (still a minority of the population in premodern times). As Timothy Barrett remarks, "Chinese Buddhism and Daoism grew up together in an environment in which a strong sense of religious identity was probably available only to a minority - to the properly-ordained Chinese Buddhist monk who had absorbed an accurate knowledge of the religion from a foreign master; to the priest or 'libationer' within a movement which still maintained the reforming zeal and hostility to popular religion of its late Han founders."4 For the majority, religion was primarily a matter of worshiping at local temples and supplicating gods, avoiding ghosts and defeating demons, living a virtuous life, staving off illness, and securing an ultimately satisfying afterlife for oneself and one's ancestors. This is not to deny that shared ritual practices fashioned communities and provided them with a strong sense of identity. ${ }^{5}$ Yet for most people, institutional religious affiliation mattered less, whether in the early centuries when Daoist and Buddhist movements competed with local cults or in the twentieth century after the modern state instituted the five religious patriotic organizations (for Daoists, Buddhists, Muslims, Protestants, and Catholics). Hence, even for the task of understanding Buddhism and Daoism, limiting one's vision to Buddhism and Daoism (however they are defined) fails to provide a picture of the whole phenomenon.

\section{The Question of Sources}

The articles in this issue also cast a critical, productive eye upon the sources used to study Chinese religion. The overwhelming size of the modern Buddhist and Daoist canons would seem to be both a blessing and a curse. Or, to use indigenous metaphors, perhaps it would be more accurate to consider the Dazangjing 大藏經 a translation of holy words promising great insight or life-long confusion, and the Daozang 道藏 a library capable of opening vistas or inducing mania. The Tang-

4. T.H. Barrett, "Taoism and Chinese Buddhism," in The Routledge Encyclopedia of Taoism, edited by Fabrizio Pregadio (London and New York: Routledge, 2008), 145. For fuller treatments of the cultural space of religion and question of religious identity, see Robert F. Campany, "On the Very Idea of Religions (in the Modern West and in Early Medieval China)," History of Religions 42, no. 2 (2003): 287-319; and Jacques Gernet, China and the Christian Impact: A Conflict of Cultures, translated by Janet Lloyd (New York: Cambridge University Press, 1985), 64-104.

5. Franciscus Verellen argued in "Evidential Miracles in Support of Taoism: The Inversion of a Buddhist Apologetic Tradition in Late T'ang China," T'oung Pao 78 (1992): 217-63, that interreligious strife under the Tang was essentially linked to tensions and rivalries at the level of clerical and lay communities. 
dynasty Buddhist canon as defined by Zhisheng 智昇 (669-740) in the Catalog of Buddbist Works in the Kaiyuan Era (Kaiyuan shijiao lu 開元㩐教錄), submitted to the throne in 730, stipulates that 1,076 texts comprising 5,048 juan 卷 (scrolls) held in 480 wrappers belong in the canon, consisting of the tripitaka of sütra, vinaya, and śástra, plus works by Chinese sages and worthies (biographies, histories, catalogs, etc.). The Daoist canon of the Ming dynasty, completed in 1445 and first printed in 1447 , contains some 1,500 different works in 4,551 juan (volumes). 6 The quantity of material in these collections has yielded tremendous insights into Chinese religion. It is no exaggeration to say that most of our knowledge about Buddhism and Daoism - and much of our understanding of medicine, astronomy, biography, textual interpretation, and other fields - has come from the close study of these two canons. Yet only in the past fifty years have scholars brought a more critical eye to understanding the historicity-the insights and the biases, the emphases and the oversights - of these bodies of texts.

Erik Zürcher pinpointed the problems and suggested solutions to them in "Perspectives in the Study of Chinese Buddhism," written in 1982. Although focused on Buddhist sources, most of his remarks apply mutatis mutandis to the Daoist canon as well, which we indicate below in brackets. Zürcher outlines three paradoxes:

First, that our view of Chinese Buddhism [or Daoism] as a historical phenomenon is greatly obscured by the abundance of our source materials. Second, that if we want to define what was the normal state of medieval Chinese Buddhism [or Daoism], we should concentrate on what seems to be abnormal. Third, if we want to complete our picture of what this Buddhism [or Daoism] really was, we have to look outside Chinese Buddhism [or Daoism] itself.?

Zürcher was concerned with the prejudices of the authors of texts in the Buddhist canon and the broader social forces involved in the institutionalization of the canon. Its authors and compilers were overwhelmingly members of the literate elite who took an exclusive view toward religious affiliation. For them, Buddhism provided a unique message, and being Buddhist was a distinctive identity, not to be confused with Daoism or the practices of popular religion.

We believe that the contributors to this issue of Cabiers advance, explicitly or implicitly, the agenda laid out by Zürcher. Many of the authors consciously utilize other types of written material that have escaped the strictures of canonical conformity. Others subject their canonical material to rigorous criticism. Others seek out visual sources or stress the material nature of unique manuscript remains. Some of the contributors demonstrate the ways in which Buddhism and Daoism were complex and multi-layered rather than monolithic. Virtually all of the essays emphasize forms of practice that could be considered both Buddhist and Daoist (or neither Buddhist nor Daoist). The article in the first section on "Thought and

6. Figures from Kaiyuan shijiao $l u$, Zhisheng (669-740), $T$ no. 2154, 55: 700c; Kristofer Schipper and Franciscus Verellen, eds., The Taoist Canon: A Historical Companion to the Daozang, 3 vols (Chicago: The University of Chicago Press, 2004), vol. I, 2.

7. Erik Zürcher, "Perspectives in the Study of Chinese Buddhism," Journal of the Royal Asiatic Society (1982): 162. 
Practice" deals with cultivating sagehood, the essays in the section on "Ritual" take up communal and mortuary ritual, and the practice of monasticism, those in the section on "Spells and Talismans" address the reproduction of spells, the practice of divination, and making seals, and the article in the final section on "Local Religion and Popular Cults" examines the building of pantheons through the canonization of local deities.

\section{Areas of Recent Research}

As our discussion above suggests, understanding the significant overlap between Buddhism and Daoism has been hampered not only by the declarations of the traditions themselves - since to outsiders claims about radical difference in matters religious often appear to turn on fine points of distinction-but also by the insular nature of modern academic disciplines. Buddhologists are usually trained to aim beyond the immediate Chinese context and to trace Buddhism back to its ostensible roots in India, while scholars of Daoist studies, steeped in Sinology, are encouraged to emphasize the Chineseness of their material. In recent years the field has entered a new phase, manifest in these essays, in which scholars who normally pursue specialized research in one of the traditions engage in conversation with scholars working in the other tradition. Virtually all of the contributors analyze problems that in this sense are comparative.

As a result of both new paradigms and a close focus on the continuing question of religious interchange, what new areas have been covered? This brief editorial introduction is not the appropriate place to review the whole field, and indeed, recent advances in the study of Buddhism and Daoism are covered in other publications, electronic and print. ${ }^{8}$ However, we think it important to note some of the important work in the subfield that some scholars have called Buddho-Daoism, bouddho-taoïsme, bukkyō to dōkyō 仏教と道教, or, more diffusely, sanjiao ronghe 三教融合 (fusion of the three teachings, Confucianism, Daoism and Buddhism).

Recent work in many ways builds on the foundation laid by our Chinese and Japanese colleagues. Fu Qinjia 傅勤家, for instance, devotes two chapters of his 1937 History of Chinese Daoism to Buddhist-Daoist interchange and polemic, pointing out similarities and borrowings between the two traditions as well as particular features

8. In Daoist studies, for example, recent surveys of the field oriented toward scholars include Livia Kohn, ed., Daoism Handbook, Handbuch der Orientalistik, sec. 4, vol. 14 (Leiden: E.J. Brill, 2000); Pregadio, The Routledge Encyclopedia of Taoism; Schipper and Verellen, eds., The Taoist Canon. In Buddhist studies, recent advances in electronic databases for both primary and secondary sources are perhaps most important, including the various projects sponsored by the Chinese Buddhist Electronic Text Association (CBETA); the Digital Dictionary of Buddhism; Indian and Buddhist Studies Treatise Database (INBUDS); and The SAT Daizōkyō Text Database; as well as the emerging entries for Buddhism in Oxford Bibliographies Online. Cabiers d'Extrême-Asie and Journal of Chinese Religions also provide crucial and up-to-date surveys. 
shared by Daoism and Tantric forms of Buddhism. ${ }^{9}$ Similarly, Tang Yongtong's 湯 用䑣 monumental 1938 history of Buddhism before the Sui dynasty has many pages on such topics as The Scripture on Great Peace (Taiping jing 太平經), joint sacrifices to Laozi and the Buddha, and dark learning (xuanxue 玄學). ${ }^{\circ}$ Virtually every major study of early Buddhism or Daoism written after these works, whether in Japanese (e.g., Tsukamoto Zenryū's 塚本善隆 1942 history), French (e.g., Maspero's posthumous 1950 work), or English (e.g., the histories by Zürcher in 1959 and Ch'en in 1964), devotes attention to the interaction between the two traditions. "

The 1970's and 1980's were formative years for European and North American scholarship on the interaction between Buddhism and Daoism. The scholarship of Erik Zürcher and Anna Seidel was fundamental. Zürcher's groundbreaking study of Buddhist influences on early Daoism was important for its systematic, comprehensive approach to a large number of texts, especially those in the Lingbao corpus. ${ }^{12}$ Zürcher concludes that in "soft" areas such as afterlife concepts and notions of guilt there was much Buddhist influence, whereas "hard" sectors of Daoism (concepts of the body, longevity techniques, etc.) remained less permeable to Buddhist loans. Subsequent scholarship by Stephen Bokenkamp and others has quarreled with where the line between hard and soft should be drawn and suggested other frameworks, but has not rejected the general approach. ${ }^{13}$ More than twenty years after its publication, Seidel's "Chronicle of Taoist Studies in the West, 1950-1990" still transcends the words in its title. Based on a sophisticated understanding of the problem of sources, Seidel's article identifies and analyzes the dominant paradigms in the field. ${ }^{14}$ In other work Seidel emphasized the broader patterns of apocalyptic frameworks and messianic hopes in Daoist materials, insisting that they

9. Fu Qinjia 傅勤家, Zhongguo daojiao shi 中國道教吏 (Shanghai: Shanghai Shangwu yinshuguan 商務印書館, 1937), esp. 154-66.

10. Tang Yongtong, Han Wei Liangjin Nanbeichao fojiao shi, supra.

II. Tsukamoto Zenryū 塚本善隆, Shina bukkyō shi kenkyū: Hoku-Gi ben 支那佛数史研究: 北魏篇 (Tōkyō: Kōbundō 弘文堂, 1942); translated by Leon Hurvitz, A History of Early Cbinese Buddbism: From Its Introduction to the Death of Hui-yüan, 2 vols. (Tōkyō: Kōdansha, 1985); Maspero, “An Essay on Taoism in the First Centuries A.D."; Zürcher, The Buddbist Conquest of China; Kenneth K. S. Ch'en, Buddhism in China: A Historical Survey (Princeton: Princeton University Press, 1964).

12. Erik Zürcher, "Buddhist Influence on Early Taoism: A Survey of Scriptural Evidence," T'oung Pao 66, nos. I-3 (1980): 84-147.

13. See Stephen R. Bokenkamp, "Sources of the Ling-pao Scriptures," in Tantric and Taoist Studies in Honour of R. A. Stein, vol. 2 (Mélanges chinois et bouddhiques, 21), edited by Michel Strickmann (Brussels: Institut belge des hautes études chinoises, 1983), 434-86 ; and more recently, idem, "The Silkworm and the Bodhi Tree: The Lingbao Attempt to Replace Buddhism in China and Our Attempt To Place Lingbao Taoism," in Religion and Chinese Society: A Centennial Conference of the École frarı̧aise d'Extrême-Orient, 2 vols., edited by John Lagerwey (Hong Kong and Paris: Chinese University Press and École française d'Extrême-Orient, 2004), 317-39.

14. Anna Seidel, "Chronicle of Taoist Studies in the West, 1950-1990," Cabiers d'ExtrêmeAsie 5 (1989-1990): 223-347. 
be understood as generic phenomena evident also in Buddhist materials. ${ }^{15}$ Subsequent work on both Buddhist and Daoist sources has extended the same approach. ${ }^{16}$

With his thesis published as a book and early articles on Daoism together with his later books and articles on Buddhism, Michel Strickmann's oeuvre is perhaps the grandest monument to Buddho-Daoist studies. His fifteen years of teaching at the University of California, Berkeley, also had a fructifying effect on the field. Strickmann's way of framing his research was to identify the underlying ritual structure or broader religious conception at work in particular Buddhist and Daoist practices. This ability to step back from the materials and analyze their structure helped him to conccptualize the ritual and social landscape of Chinese religion in capacious terms. His Chinese Magical Medicine (2002), for instance, looks at the different etiologies and therapies adopted in Buddhist and Daoist milieux, treating both traditions under the rubric of religious healing. ${ }^{17}$ The same could be said for his book on divination and his article on the practice of sealing. ${ }^{8}$ His magisterial study of esoteric Chinese Buddhism, Mantras et mandarins (1996), lays out a research program that distinguishes between the Tantric model of identification betwreen devotee/host and deity/guest, ultimately based on Vedic paradigms, and the Daoist ritual structure involving submission of a written memorial or bureaucratic communiqué. By shifting attention away from the question of religious affiliation and toward the structure of ritual and the aims of religious practice, Strickmann laid the groundwork for further research on ritual technologies such as spells, exorcism, divination, medicine, and seals. ${ }^{9}$ He attempted to trace "the degree to which

15. Anna Seidel, "The Image of the Perfect Ruler in Early Taoist Messianism: Lao-tzu and Li Hung," History of Religions 9 (1969-1970): 216-47; idem, "Taoist Messianism," Numen 31 (1983): 161-74.

16. Erik Zürcher, "Eschatology and Messianism in Early Chinese Buddhism," in Leyden Studies in Sinology: Papers Presented at the Conference Held in Celebration of the Fiftieth Anniversary of the Sinological Institute of Leyden University, December 8-12, 1980, edited by W. L. Idema (Leiden: E. J. Brill, 1981), 34-55; idem, "Prince Moonlight: Messianism and Eschatology in Early Medieval Chinese Buddhism," T'oung Pao 68 (1982): I-75; Michel Strickmann, "The Consecration Sütra: A Buddhist Book of Spells," in Chinese Buddbist Apocrypha, edited by Robert S. Buswell, Jr. (Honolulu: University of Hawai'i Press, 1990), 75-118; Christine Mollier, Une apocalypse taoïste du $v$ siècle : le livre des incantations divines des grottes abyssales, Mémoires de l'Institut des hautes études chinoises (Paris: Collège de France, Institut des hautes études chinoises, 1990).

17. Michel Strickmann, Cbinese Magical Medicine, Asian Religions and Cultures, edited by Bernard Faure (Stanford: Stanford University Press, 2002).

18. Michel Strickmann, Chinese Poetry and Prophecy: The Written Oracle in East Asia, Asian Religions and Cultures, edited by Bernard Faure (Stanford: Stanford University Press, 2005); idem, "The Seal of the Law: A Ritual Implement and the Origins of Printing," Asia Major, third series, 6 (1993): I-83.

19. On spells, see Paul Copp, The Body Incantatory: Spells and the Ritual Imagination in Medieval Chinese Buddhism (New York: Columbia University Press, forthcoming); on exorcism, see Edward L. Davis, Society and the Supernatural in Song China (Honolulu: University of Hawai'i Press, 200I); on divination, see Marc Kalinowski, ed., Divination et société dans la Chine médiévale : étude des manuscrits de Dunbuang de la Bibliothèque nationale de France et de la British Library (Paris: Bibliothèque nationale de France, 2003); on medicine, see Catherine Despeux., 
Buddhist and Daoist specialists eventually came to share a common ritual idiom by the fifth century." ${ }^{20}$ His particular focus was on the medieval period, more or less, but the insights gained from the approach could be applied to other periods as well. In addition, Strickmann linked, as far as the sources would allow, the analysis of ritual to the question of Who? (which religious specialists carried out the rituals?) and For whom? (for which clienteles?). The sociological question has proven important for early ritual, where the lack of sources obstructs our knowledge of social context, as well as for religious practice from the Song and later dynasties, when the profusion of documents makes it easier to conceive of the full range of religious practice at the local level. ${ }^{2 t}$ Building on Strickmann's claims, a significant amount of research on the complexities of the interaction between Daoist and Tantric ritual has also appeared more recently.22

Scholarship over the past twenty years has been marked by an interest in ritual, a preference for elements shared by Buddhism and Daoism, and a general openness on the part of specialists in one tradition to converse with specialists in the other. Concepts of the afterlife, mortuary ritual, and the bureaucracy of the otherworld have been important topics in Buddhism and Daoism. ${ }^{23}$ Seasonal festivals have also

ed., Médecine, religion et société dans la Chine médiévale, étude de manuscrits chinois de Dunbuang et de Turfan, 3 vols. (Paris: Collège de France, Institut des hautes études chinoises, 2010); on seals, see James Robson, "Signs of Power: Talismanic Writing in Chinese Buddhism," History of Religions 48, no. 2 (2008): 130-69.

20. Strickmann, "The Seal of the Law," 6.

2I. For a focus on ritual with attention to its social background during the early periods, see Franciscus Verellen, "The Heavenly Master Liturgical Agenda According to Chisong zi's Petition Almanac," Cabiers d'Extrême-Asie I4 (2004): 291-343; and Peter S. Nickerson, "Taoism, Death, and Bureaucracy in Early Medieval China" (Ph.D. dissertation, University of California, Berkeley, 1996). On the later period, see Davis, Society and the Supernatural in Song China.

22. See, for instance, the first two of three recent studies of rain-making ritual: Joshua Capitanio, "Dragon Kings and Thunder Gods: Rainmaking, Magic, and Ritual in Medieval Chinese Religion" (Ph.D. dissertation, University of Pennsylvania, 2008); Mark Meulenbeld, "Civilized Demons: Ming Thunder Gods from Ritual to Literature" (Ph.D. dissertation, Princeton University, 2007); and Jeffrey Snyder-Reinke, Dry Spells: State Rainmaking and Local Governance in Late Imperial China (Cambridge, MA: Harvard University Asia Center, 2009). For listings of parallel passages in Daoist and Tantric texts, see Xiao Dengfu 登福, Daojiao yu mizong 道教 與密宗 (Taipei: Xinwenfeng 新文豐, 1993). For a some of the hermeneutical issues at stake, see Charles D. Orzech, "Fang yankou and Puáu: Translation, Metaphor, and Religious Identity," in Daoist Identity: History, Lineage, and Ritual, edited by Livia Kohn and Harold D. Roth (Honolulu: University of Hawai'i Press, 2002), 213-34.

23. On the dead, see Stephen F. Teiser, "The Scripture on the Ten Kings" and the Making of Purgatory in Medieval Cbinese Buddhism, Kuroda Institute, Studies in East Asian Buddhism, 9 (Honolulu: University of Hawai'i Press, 1994); Stephen Bokenkamp, "Death and Ascent in Ling-pao Taoism," Taoist Resources I, no. 2 (1989): 1-17; idem, Ancestors and Anxiety: Daoism and the Birth of Rebirth in China (Berkeley: University of California Press, 2007); Livia Kohn, "Steal Holy Food and Come Back as a Viper: Conceptions of Karma and Rebirth in Medieval Daoism," Early Medieval China 4 (1998): 1-48. 
been a focus. ${ }^{24}$ Social historians have been particularly interested in the Chinese pantheon, or perhaps more appropriately, pantheons-general systems of gods or deities. Conceptions of divinity, the attempts of religious and political institutions to advance or quash religious cults, and the multivocality of deities as religious symbols have been important points of contention. ${ }^{25}$

For cases in which institutional commitments or self-consciously proclaimed doctrines more clearly separate Buddhism and Daoism, scholarship has also entered a new era. Recent studies of Chinese philosophy have adopted a supple approach to the question of translation, cultural interchange, and linguistic borrowing. ${ }^{26}$ Other scholars have focused on state control of religion. ${ }^{27}$ Other recent

24. Ian Chapman, "Festivals and Ritual Calendars: Jing-Cbu suishi ji," in Early Medieval Cbina: A Sourcebook, edited by Wendy Swartz, Robert Ford Campany, Yang Lu, and Jessey Choo (New York: Columbia University Press [forthcoming]); Paul R. Katz, Demon Hordes and Burning Boats: The Cult of Marshal Wen in Late Imperial Chekiang (Albany: SUNY Press, 1995); Stephen F. Teiser, The Ghost Festival in Medieval China (Princeton: Princeton University Press, 1988).

25. Important selections from a long list include: Valerie Hansen, Changing Gods in Medieval Cbina, $1127-1276$ (Princeton: Princeton University Press, 1990); idem, "Gods on Walls: A Case of Indian Influence on Chinese Lay Religion?" in Religion and Society in T'ang and Sung Cbina, edited by Patricia Buckley Ebrey and Peter N. Gregory (Honolulu: University of Hawai'i Press, 1993), 75-113 ; Robert P. Hymes, Way and Byway: Taoism, Local Religion, and Models of Divinity in Sung and Modern China (Berkeley: University of California Press, 2002); Paul R. Katz, Images of the Immortal: The Cult of Lü Dongbin at the Palace of Eternal Joy (Honolulu: University of Hawai'i Press, 1999); Terry F. Kleeman, "The Expansion of the Wen Ch'ang Cult," in Religion and Society in T'ang and Sung China, 45-74; idem, A God's Own Tale: The Book of Transformations of Wenchang, the Divine Lord of Zitong (Albany: SUNY Press, 1994); Livia Kohn, God of the Dao: Lord Lao in History and Myth (Ann Arbor, MI: University of Michigan, Center for Chinese Studies, 1998); Zhiru Ng, The Making of a Savior Bodhisattva (Honolulu: University of Hawai' i Press, 2007); Meir Shahar and Robert P. Weller, eds., Unruly Gods: Divinity and Society in Cbina (Honolulu: University of Hawai $i$ Press, 1996); Michael Szonyi, "The Virgin and the Chinese State: The Cult of Wang Yulan and the Politics of Local Identity on Jinmen (Quemoy)," Journal of Ritual Studies 19, no. 2 (2005): 87-98; James Watson, "Standardizing the Gods: The Promotion of T'ien Hou ('Empress of Heaven') along the South China Coast, 960-1960," in Popular Culture in Late Imperial and Modern China, edited by David L. Johnson, et al. (Berkeley: University of California Press, 1985), 292-324; Chün-fang Yü, Kuan-yin: The Chinese Transformation of Avalokitesvara (New York: Columbia University Press, 2001).

26. T.H. Barrett, Li Ao: Buddhist, Taoist, or Neo-Confucian? (Oxford: Oxford University

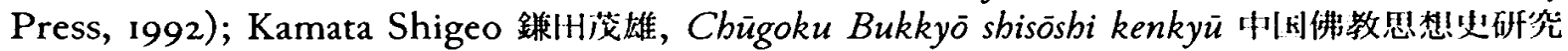
(Tokyo: Shunjūsha 隹秋社, 1968); Victor H. Mair, “What is Geyi, after All?" in Philosophy and Religion in Early Medieval China, edited by Alan K. L. Chan and Yuet-Keung Lo (Albany: SUNY Press, 2010), 227-64; Robert H. Sharf, Coming to Terms with Chinese Buddbism: A Reading of the "Treasure Store Treatise," Kuroda Institute, Studies in East Asian Buddhism, 14 (Honolulu: University of Hawai'i Press, 2002).

27. For the Tang: T.H. Barrett, Taoism under the T'ang: Religion and Empire during the Golden Age of Chinese History (London: Wellsweep Press, 1996); Stanley Weinstein, Buddbism under the T'ang (Cambridge: Cambridge University Press, 1987); Howard J. Weschsler, Offerings of Jade and Silk: Ritual and Symbol in the Legitimation of the T'ang Dynasty (New Haven: Yale University Press, 1985); David L. McMullen, "The Death Rites of Tang Daizong," in State and Court Ritual in Cbina, edited by Joseph P. McDermott (Cambridge: Cambridge University 
studies consider ideals of saintliness and asceticism as well as the institutions of monasticism. ${ }^{28}$

Like the world of transformation plumbed by Chinese divinatory techniques, the study of Buddhism, Daoism, and Chinese religion is far from settled. Three recent monographs have provided both careful analysis and broader conclusions. Stephen Bokenkamp's 2007 study reveals the multiplicity of ideas and the continuing anxiety about rebirth, aggravated but not determined by Buddhism, within early Daoism. Christine Mollier's 2008 book focuses on the importance of the local ritual specialist and the complex ways in which religious practices could flow between Buddhism and Daoism. James Robson's 2009 volume suggests that localized practice and boundedness to place, perhaps more than religious affiliation, played a determinative role in the construction of Buddhist and Daoist pilgrimage centers. ${ }^{29}$ We believe that the articles in this issue of Cabiers d'Extrême-Asie represent solid research that adds importantly to these recent syntheses.

We want to express our special appreciation to two sponsors of the 2010 conference, the David A. Gardner '69 Magic Project (Council on the Humanities of Princeton University) and the École française d'Extrême-Orient, for their financial and moral support that proved no small undertaking in light of the international travel and different languages involved. We are particularly happy that the conference as well as the resulting publication focus so significantly on practices that can be considered "magical" by almost any cultural yardstick, with many articles focusing on divine surveillance, spells, malevolent deities, divination, mortuary practice, ritual theory, sanctity, and astrology. Other sponsors included Princeton University's Program in East Asian Studies (The Mercer Trust), Center for the Study of Religion, and the Buddhist Studies Workshop, to whom we also express our thanks. Barbara Bermel in the Center for the Study of Religion and Douglas Gildow, Ph.D. student in Religion, were particularly generous with their time and expertise in making the proceedings go smoothly.

Press, 1999), 150-97. For the modern period, see Yoshiko Ashiwa and David L. Wank, eds., Making Religion, Making the State: The Politics of Religion in Modern China (Stanford: Stanford University Press, 2009): Mayfair Mei-hui Yang, ed., Chinese Religiosities: Afflictions of Modernity and State Formation (Berkeley: University of California Press, 2008); Vincent Goossaert and David A. Palmer, The Religious Question in Modern Cbina (Chicago: University of Chicago Press, 20II); and Anthony C. Yu, State and Religion in China: Historical and Textual Perspectives (Chicago: Open Court, 2005).

28. James A. Benn, Lori Meeks, and James Robson, eds., Buddbist Monasticism in East Asia: Places of Practice (London: Routledge, 2010); Livia Kohn, Monastic Life in Medieval Daoism: A Cross-Cultural Perspective (Honolulu: University of Hawai'i Press, 2003); Florian Reiter, The Aspirations and Standards of Taoist Priests in the Early T'ang Period (Wiesbaden: Harrassowitz, 1998).

29. Bokenkamp, Ancestors and Anxiety; Christine Mollier, Buddbism and Taoism Face to Face: Scripture, Ritual, and Iconogrupbic Exchange in Medieval China (Honolulu: University of Hawai' $\mathrm{i}$ Press, 2008); James Robson, Power of Place: The Religious Landscape of the Southern Sacred Peak (Nanyue) in Medieval China, Harvard East Asian Monographs, 316 (Cambridge, MA: Harvard University Asia Center, 2009). 
We are grateful to the authors, who responded quickly and carefully to our many queries. In addition, Phyllis Brooks Schafer, Lü Pengzhi, Benoît Jacquet, and Iyanaga Nobumi provided expert help throughout the production of the volume, answering our ill-timed editorial questions with alacrity and grace.

Several scholars presented papers at the 2010 conference that are being published elsewhere; their written and oral interventions were crucial to the success of the whole enterprise, and we wish to thank them here. They are: Robert F. Campany (Vanderbilt University), Edward L. Davis (University of Hawai i), Terry Kleeman (University of Colorado), Kuo Liying 郭麗英 (École française d'Extrême-Orient), John Lagerwey (Chinesc University of Hong Kong), Christine Mollier (Centre national de la recherche scientifique), Mugitani Kunio 麥谷邦夫 (Kyoto University), James Robson (Harvard University), Robert Sharf (University of California, Berkeley), and Zhou Yukai 周裕锴 (Sichuan University). Robert M. Gimello (Notre Dame University) and Michael Puett (Harvard University) commented incisively on every paper presented at the conference; their breadth of vision helped keep discussion focused on the larger questions, and we would like to express our gratitude for their contributions. Three other scholars, Timothy H. Barrett (University of London), Liu Yuan-ju 劉苑如 (Academia Sinica), and Anthony C. Yu (University of Chicago), were involved in our planning over the years but were unable to join us for the conference. We thank them for their support and inspiration. 